\title{
Political Theology as Theodicy: The Holy Spirit's Performance in the Economy of Redemption*
}

\section{MARTÍN GRASSI}

Catholic University of Argentina, Faculty of Philosophy and Literature-National Council for Scientific and Technical Research of Argentina martingrassi@uca.edu.ar

ORCID: 0000-0002-9378-6254

\begin{abstract}
Although Political Theology examined mainly the political dimension of the relationship between God-Father and God-Son, it is paramount to consider the political performance of the Holy Spirit in the Economy of Redemption. The Holy Spirit has been characterized as the binding cause and the principle of relationality both referring to God's inner life and to God's relationship with His creatures. As the personalization of relationality, the Holy Spirit performs a unique task: to bring together what is apart by means of organisation. This power of the Spirit to turn a plurality into a unity is manifested in the Latin translation of oikonomía as disposition, that is, giving a special order to the multiple elements within a certain totality. Within this activity of the Spirit, Theodicy can be regarded as the way to depict God's arrangement of the world and of history, bringing everything together towards the eschatological Kingdom of God. The paper aims at showing this fundamental activity of the Holy Spirit in Christian Theology, and intends to pose the question on how to think on a theology beyond theodicy, that is, how to think on a Trinitarian God beyond the categories of sovereignty and totalization.
\end{abstract}

Keywords: theodicy; political theology; Holy Spirit; economy; sovereignty.

This paper is an output of the project "The Problem of Evil: From Leibniz to Analytic Philosophy of Religion” (FFI2017-84559-P: Ministerio de Ciencia e Innovación, Gobierno de España). 


\section{The Holy Spirit faces Political Theology}

The term theology ( $\theta \varepsilon \circ \lambda$ oүí $\alpha$ ) appears for the first time in Plato's Republic (379a), within a political debate on how to raise good citizens for an ideal city. Since then, theology and politics were destined to walk together, and, far from being independent one from the other, became territories engaged in a permanent commerce, sharing and borrowing concepts, metaphors, notions, and arguments from each other. Political Theology is, today, the discipline in charge of examining these interconnections, a discipline born in the twentieth century. Whether our modern political concepts are secularised theological concepts (Schmitt 2009), or theological concepts are "theologised" political concepts (Assmann 2000), it is quite clear that theology and politics are profoundly intertwined. I will argue in this paper for a two-way influence between the two, and that concepts such as 'glory', 'sovereignty' or 'government' are signatures that "move and displace concepts and signs from one field to another (in this case, from sacred to profane, and vice versa) without redefining them semantically" (Agamben 2011, 4).

These displacements become especially complicated when they refer to politics and Christian theology. In Erik Peterson's perspective, if the analogies between God's sovereignty and the political ruler on earth were built upon the idea of unity and peace, both the dogma of the Trinity and the eschatological nature of the Kingdom of God made this analogical procedure an impossible one, and, therefore, there is no Christian political theology (1950). Peterson's dismissal of political theology as such, however, seems to overlook the political scheme of Christianity, as Schmitt (1970) later replied. Giorgio Agamben (2011) has recently argued that the novelty that the notion of the Trinity offers to Christian theology is to be found in its redefinition of the political (the question of sovereignty) in terms of economy (the question of administration and government).

The notion of the Trinity transfigures the meanings of both monotheism and monarchy (Peterson 1950; Moltmann 2002b): Christianity is not merely a mono-theism, because the Christian God is Trinitarian, being God Himself a community of persons. Since Karl Rahner's work begun 
the Trinitarian renaissance in the twentieth century, the question of the Trinity cannot be considered as something secondary, but as the very core topic of Christian theology (Rikhof 2009). Yet, the way to conceptualise the Trinity by not giving up on God's Oneness has been - and still is - an unsurpassable challenge. This difficulty, rather than being an ontological issue, is a political one: how can we praise God as the One and Only Lord of history and the world, if there are other divine figures that could contest His sovereignty? From the beginning of Christian theology, the Trinity was a matter of how the power of God could be shared by more than one person. On the one hand, the fights against Arianism led to acknowledge Jesus as the Son of God, the second Person of Trinity, in terms of sharing the Lordship in the name of His Father. The fight against Pneumatomachi (or Semi-Arians) was held, on the other hand, to claim the divinity of the Holy Spirit. Basil of Caesarea argued that the Baptism formula - Glory to the Father, through the Son, with the Holy Spirit - "manifests the equality

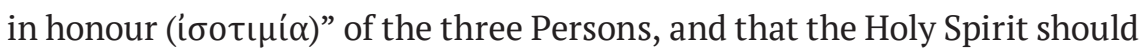
be, then, considered as being God (De Spiritu Sancto, VI, 13, 16). The question was, thus, how to understand this shared political sovereignty. How to articulate these "two hands of God" (using Irenaeus of Lyon image) without putting into question the sovereignty of God the Father, was especially examined by the Early Christian theology, in a difficult compromise between monarcheia and oikonomía (Uríbarri 1996).

Although through its early history political theology mostly looked into the relationship between God-Father and God-Son, the importance of the Holy Spirit cannot be ignored, for its role in the economy of redemption is mostly to perform God's plan in the world. The Holy Spirit was mainly conceptualised as God's linking principle, relating God with the World, God with the Church, and, God with Himself, bringing the Father and the Son together. Its relational nature made the Spirit a very fuzzy figure within theology and its performative nature within creation, incarnation, eschatology and liturgical celebration made it difficult for Christian theology not to conceptualise it as if were just God's activity. In effect, whereas the Father and the Son were conceptualised by the idea of person, the personhood of the Spirit was always somehow problematic: 
there is a kind of kenosis of the Holy Spirit, by which it empties "itself in some way from its own personality to be absolutely relative" (Congar 1981, I, 7-8). Still, because of the political meaning of the verbs "to link", "to relate", and "to hold together", the Holy Spirit is not simply one more element to look at regarding the mutual commerce between politics and theology: I will claim that the key to Christian political theology resides in this ghostly figure.

\section{The Economic Activity of the Holy Spirit}

The Holy Spirit is usually conceived of as the principle of relationality. The Holy Spirit relates not only the Father with the Son and performs community within God's Life (immanent Trinity), but also brings the Divine and human realms together (economic Trinity). Thus, one may argue that there is no unity without the third, without the very element of relationality: more than One is already Three. The Holy Spirit performs community in every stage: the community of persons within God, the community of human beings, the community of the universe, and the community between God and men. This is why the Holy Spirit is ambivalent and ambiguous, both personal and impersonal, for it is not only related with the other Persons of the Trinity (as they all are), but it is in itself relationality. Hence, as Jürgen Moltmann (1992) argued, the names given to the Holy Spirit are always given a posteriori, as an expression of the kind of relationship it performs: between Father and Son, its name is Love, or Mother; and between the Father and human beings, it is called the Paraclete; and so on.

It seems convenient, then, to examine the political dimension of this pneumatological performance within Christian political theology. When addressing God in the creed, Christians refer to Him as Lord, calling Him

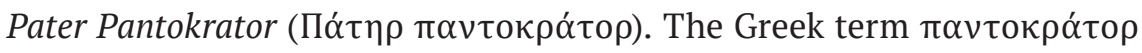
does not refers purely to a concept of power, but to a political and relational notion. Although the Latin translation to omnipotens led theology to reflect on the tension between the possible and the impossible re-

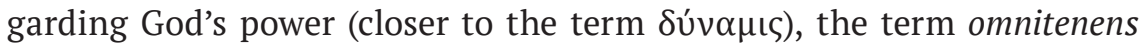
was also used as a possible translation that Augustine used, meaning that 
God is Sovereign in relation with His creatures in holding the creation together (Batut 2009, 502). The medical-physiological discourse meet the theological and the political, for the history of salvation ( $\sigma \omega \tau \varepsilon \rho i \alpha)$ is the history of God as the life-giver, being health the opposite of disease, that is, disaggregation or disorganisation, or even decomposition, being the verb $\sigma \omega \dot{\zeta} \omega$ the one that enables these semantical displacements (Congar 1975, 103-110). This interconnection between physiology and theology is even stronger if one examines the very concept of spirit $(\pi v \varepsilon \tilde{u} \mu \alpha)$, which was at the very centre of Aristotelian and Galenic biology, and in the

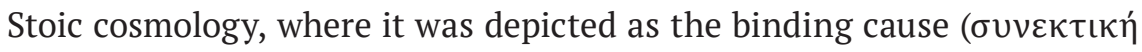
$\alpha_{i}^{\prime} \tau^{\prime} \alpha$ ) of the universe (Verbeke 1945). Therefore, it seems that the world is saved because it is kept together, because it is organised, by a single divine cause which rules over it.

In these semantic displacements between the theological, the physiological and the political, the word economy (оíкоvонí $\alpha$ ) comes forth (Grassi 2019). Economy is the art of administrating, governing, and disposing what is proper. As mainly referring to the administration of the household, economy has a monarchic structure, for the only master ( $\delta \varepsilon \sigma \pi$ ó $\tau \uparrow)$ of the house is the father. This monarchic and patriarchal scheme is found in the trinitarian relationship of Father and Son. This economic relationship defines the soteriological mission of Jesus Christ in history by defining the way in which the Son is obedient to the rule of the Father and acts on His behalf. Perhaps one of the reasons for political theology to be mostly interested in the Father-Son relationship is the Latin translation of oíкоvо $\mu$ í $\alpha$ as dispensatio, which referred to the Lordship of the Son over history until the Kingdom of God comes, when He will give the power back to the Father. In the midst of the debate with Arianism, Tertullian claimed for the divinity of Jesus Christ within a theologico-political scheme. On the one hand, he argued that monarchy should not be understood as the rule of a single person, but as the unity of power (unicum imperium). Both the economic structure of the household (where the father administrates along with the son), and the Imperial Roman structure of the diuumvirate (that is a dual ruling), served Tertullian to argue for this new understanding of monarchy, which did not rule out the pos- 
sibility of the Father sharing His power with the Son (Adversus Praxean, III, 23ss). On the other hand, the Son's sovereignty is presented in terms of dispensatio, for the Son is the vicar of the Father during human history, until the end of times, when the lordship of the Father will be restored by the Son (Tertullian, Adversus Praxean, IV, 33-35).

A different Latin translation for oíкоvонía, however, is dispositio. In a like manner as in dispensatio, the political dimension of theology comes forth as well with this translation, for the ruling of God over the world performs a well-arranged totality by means of His administration. It is this second meaning of economy that brings forth the importance of the Holy Spirit, for the Spirit, first, disposes the members of the Church as one body by its grace through the sacraments and charismas; it also disposes the elements of the world in order to constitute a totality (in analogy with a organisms); it disposes, as well, the events of history towards its eschatological goal; and it disposes the grammatical elements towards meaning (the Pauline dialectics of $\gamma \rho \alpha \mu \mu \alpha-\pi v \varepsilon \tilde{u} \mu \alpha$ ). The idea of dispensatio, thus, becomes dependent on the idea of dispositio. If dispensatio refers to the work of Jesus as the provisional ruler over history by the Father's anointment, dispensation is but describing a particular moment within the whole economy of Redemption, by which the Spirit disposes every event and every creature towards God's glorious Kingdom. This dependency of the Son upon the Spirit could be notice in, at least, two theological claims. On the one hand, in the Kingly and Priestly office of the Son, it is the Holy Spirit that conceives Jesus in Mary's womb, the one that anoints Jesus by John's Baptism, the one that resurrects Jesus from His death on the cross, the one that establishes the Church in Pentecost, and finally the one who gives a soteriological power to the sacraments, including the presence of Jesus in the Eucharist. On the other hand, the Church as the People of God, is established as the Body whose head is Jesus Christ, but animated and organised by the Spirit. In short, dispensatio could be considered within the larger logic of dispositio, and the soteriological work of Jesus within the larger economical work of the Spirit.

In its bringing things together, the Holy Spirit was called "the giver of

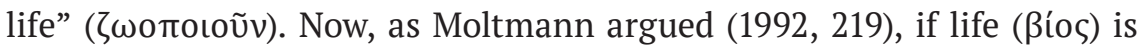


understood as living together ( $\sigma \cup \mu \beta \iota \omega ́ \sigma \iota)$, one should acknowledge the work of the Holy Spirit as vivificans because it is binding. Thus, considering the whole of Creation as the outcome of God's arrangement, the Holy Spirit is the efficacious principle of Creation as far as it binds and keeps everything together, being the cause of its being an organic totality (Pannenberg 1972). In this "cosmic" performance, the Holy Spirit is conserving creation by organising the different entities within the whole. The question on the binding performance of the Spirit, however, does not have an easy answer when facing human history, for men were created free beings. This particularity of humankind forces us to understand dispositio in a different way. Interestingly, the way to administrate and organise what is proper is linked with the ancient art of economy, which was not meant primarily to explain how to manage things, but how to dispose and rule over the people within the household: the art of economy is, thus, referred to the way the Lord treats and leads his wife, his children, and mainly his slaves (Leshem 2012). The economic scheme is essentially monarchic, for it is the father that rules indisputably over the household and, therefore, the main problem and aim of economy is how to bind the will of everyone to that of the father.

Similarly, soteriology is built upon this economic scheme, in which God the Father must rule over humankind as if they were His children. In the familiar and economic drama of history, Adam and Eve initiated a time of inner war within the divine household by disobeying God's commandment. Soon after, the divorce between men and God was to be followed by the divorce between men themselves, when Adam's own household was also divided by Cain's murder of his brother. Although the Incarnation of the Son brought men back to God's household as His children, the time of a perfect peace will be only achieved in the eschatological Kingdom of God. Hence, history seems to be, from a theological perspective, the result of different events, marked either by disobedience or by servitude to the Father's Will. Jesus Christ is, ultimately the counter-example of Adam, the one that fulfilled his duty as a son where the other failed. Hence, whereas pride (superbia) is the source of every sin, for it is out of pride that we affirm ourselves to be self-sufficient and autonomous, piety (pietas) is, con- 
versely, the primary theological virtue and the source of every other: in being pious, we acknowledge ourselves to be the servants of God because we owe everything to Him. It is not just about being humble, but about praising and acknowledging God as our sole resource of life and happiness, as our Lord: pietas is defined, thus, within the larger virtue of justice, and this is why it has mainly a political meaning. Augustine of Hippo's scheme of the two cities - the City of God and the City of Men - is but a metaphor of this theologico-political dilemma: either we love God above everything, or we love ourselves. And the one who, indwelling in our soul, turns us into servants of God and makes us participants in God's life, the power that sanctifies us, is the Holy Spirit. Hence, a blissful and peaceful life is only possible within a perfect community without any kind of inner division: the Holy Spirit is, at the same time, spiritus sanctificans and spiritus vivificans.

\section{Political Theology as Theodicy: the eschatological Kingdom of God}

The notion of the Kingdom of God articulates the way in which God rules over the world. His Lordship is performed economically, through the missions of the Trinitarian Persons. Erik Peterson stressed the eschatological nature of the Kingdom when he coined the expression "eschatological reservoir", an expression that played a major role in later political and liberation theology (Uríbarri 2003). The Kingdom of God is already, but not yet, here, and history itself is the dramatic scenario that aims at the definite coming of the One Lord. God engages history in a soteriological way and conducts it towards its final fulfilment, arranging the historical events in a single drama or plot. Hence, the history of Redemption is written not from the beginning, but from the end: "Christian theology speaks of God historically and of history eschatologically" (Moltmann 1968,372 ), and it does not begin with a "protological understanding of eschatology", but with an "eschatological understanding of creation" (Althouse 2006, 25-26). The truth of God, thus, is not yet unveiled, but must be found in its (be)coming, and history itself is driven by this paradoxical 
future that is both within and outside time (the very notion of the "end of times" points towards this paradox).

In the Kingdom of God, in this everlasting glory of His sovereignty, the truth of God will be unveiled, revelation will know no shadow. In the meantime, we can only long for God's promised Kingdom of Glory: "history is that which happens between promise and fulfilment" (Moltmann 2002a, 66). As a perfect moral agent, God's identity is defined by the ethical and political category of faithfulness (Grassi 2019). Consequently, we can have hope and have faith. God will not disappoint us, for, on the one hand, His sovereignty knows no equal competitor, and, on the other, He cannot but stay loyal to His promise. The effectiveness of God's rule is, nevertheless, not at all contested by the apparent miseries or God-forsaken events in history. As Augustine of Hippo argued in his City of God, in the midst of history, where good and evil are mingled, and God's power cannot be clearly discerned, the concept of providence, as the divine work of distributing good and bad fortune, comes forward (I, 8). Christians are good servants of God if they regard God's will as their great resource, albeit the sufferings that they must endure during their lifetime (De civitate Dei, I, 10). The justice of God will be only seen clearly in the end of times; in the meantime, "the providence of the Creator and Governor of the universe is a profound mystery" (De civitate Dei, I, 28).

The twentieth century offered a radical critique of this 'candid' trust on the fact that every event in history is simply an expression of God's rule, originated mostly in the calamities of totalitarian regimes and World wars. Modern philosophy of history, which based on the idea of progress towards a human earthly bliss, as well as the theological justification of historical events as being in God's plan, were turned into ashes in the burning of innocent children. Fiodor Dostoyevsky's rage against this naïve theological consolation (expressed in his Ivan Karamazov) became a leit motiv in the twentieth century: there cannot be any calculation that could bring into balance the death of an innocent child with a cosmic overarching goodness. As Emmanuel Levinas claimed, Auschwitz witnesses for the disproportion between suffering and theodicy (Geddes 2018: 4). 
The theological virtue that seems to ground classical theodicy is faith: although there is evil in this World, believing in a supreme God, both omnipotent and good, entails the belief that everything happens because of some reason, and that suffering makes sense if we believe in God's providence. Ultimately, this faith and this theodicy have a cosmological shape, based in a theology of logos that pictures God as the wise architect of this World: the doctrine of providence is read through the lens of that of creation (all things were set right from the beginning in God's plan). The analogies that Augustine made of God as an artist and the presence of evil as elements of contrast that work for the beauty of the whole (City of God, XI, 23) are an indication of this thought. In the light of the tragic events of twentieth century, holding on to this kind of classical theodicy seems to be, at the least, insensitive: "if only because an Auschwitz existed, no one in our age should speak of Providence", claimed Primo Levi (quoted in: Geddes 2018: 4). Still, God's Sovereignty cannot be simply dismissed, for if God is not the Lord of history, then redemption is illusory. Christianity entails the acclamation of God's sovereignty. Hence, the anchoring of a new theodicy after Auschwitz seemed to move from faith to hope. The history of redemption and God's economy is no longer understood from the proto-logical foundations of the world, within a rationalistic theological scheme, but from an eschatological horizon of history, within an ethical and political scheme. Somehow, we found in the twentieth century a recovery of Early Christian theology in a recovery of its eschatological nature (Taubes 2009): an eschatology that no longer holds an individualistic perspective on one's own salvation, but a universal one that embraces the whole of humankind.

The key to understand this new theodicy is, therefore, the concept of Kingdom of God. Redemption is not a private issue, but the ultimate expression of God's sovereignty. The Kingdom of God, however, does not come from God alone but needs human engagement: human beings are not only the passive audience witnessing God's actions in history: they are active players in the building of His kingdom. Thus, theodicy, as the question concerning God's sovereignty in the face of suffering and evil, is turned into a political issue, and the Job's cry does not end in tears, but in ethi- 
cal commitment and compassion for those who suffer. Hope is no longer a passive desire, but an active commitment to a better future to come.

The 1960's saw the meeting of Christian theology and Ernst Bloch's philosophy, with the new political theology being represented in the works of Johannes Metz (Ruz et alter 2008) and Jürgen Moltmann (1991a), built on the ideas of hope and utopia. Although the term theodicy is rarely used in this new context, the idea behind it is still working in contemporary political theology. If the term theodicy is built from the Greek words $\theta \varepsilon$ ó and $\delta ı \eta^{\prime}$, the question is not so much how to justify God in the face of suffering and evil, but rather how to make the world a place of justice: from the passive kind of apologia, where we work as lawyers in stating God's innocence concerning Auschwitz for instance, we are moved to an active meaning of $\delta \iota \kappa \eta$ as "making justice", where we walk side by side with God as His collaborators in the building of a better world. It is worth mentioning that $\delta$ ı́ does not have a material content (as passions are to temperance), but it is a relational virtue, that is, the virtue of arranging the different things in order to achieve harmony: this is why justice is behind every other virtue, for virtue is the proper way to achieve balance between opposing forces. Then, theodicy could be understood not only as the discourse that justifies God's action in the world, but also the discourse that aims at the very action by which God arranges the world as if He were a Lawgiver. In this particular understanding, political theodicy (corresponding to a political theology) would entail the premise that, although every human being is subject to the Lordship of God, not all of them are obedient to His law. The Kingdom of God will come when all men are ultimately subject to God's Law, under the example of Jesus, who was obedient to His Father even in the face of death. Political theodicy, thus, entails the need to bring the whole mankind to God's rule, and by doing so, to work for the coming of the Kingdom. 


\section{Doxology, Trinity, and the Age of the Spirit}

Maximus the Confessor produced a sound theology of deification ( $\theta \varepsilon \dot{\varepsilon} \omega \sigma \iota \varsigma)$. For him, deification is not simply another expression for redemption but its ultimate end, for it is the attainment of the original destiny of humankind that the sin of Adam interrupted. Although deification may be anticipated to some degree in this life, it can only be fully achieved eschatologically. To attain this likeness of God life must be lived ascetically, and one should attain a symbiosis with Christ through the renunciation of sensual gratification. This state, however, cannot be attained by one's own forces, but within ecclesiastical life, to which one enters through baptism, by which one is endowed with the name of Christ and receives the Holy Spirit, whose sanctifying power raises us up to the divine. "Our life in the ecclesial community is a progress from slaves to hired servants to son, from beginners to the advancing to the perfect, from the faithful to the virtuous to the gnostics" (Russell 2004, 294). This is the path to attain deification, although this is not the outcome of our natural capacities but a gift of divine grace. Hence, this path, that starts in this life with baptism, the Eucharist and moral life, will be fulfilled by grace in the age to come, when, after this active life on earth, we are transformed by the divine glory (Maximus symbolized this age of full deification by the "Eight Day").

The eschatological and political importance of deification finds in the work of Joachim of Fiore the significance and relevance that shapes our political theology today. When Karl Barth asked Jürgen Moltmann if his Theology of Hope was not only a Christianisation of Ernst Bloch's philosophy, the latter responded that it was no longer Augustine of Hippo but Joachim of Fiore who was inspiring the accounts of the Spirit in the twentieth century (De Lubac 1979, I, 7). The history of the influence of Joachim of Fiore is quite troublesome and ambivalent: he is used both by totalitarian political movements, such as communism and National Socialism (Riedl 2018), and by pluralistic and postmodern thinkers (Iiritano 2018). The theology of history of Joachim is the outcome of his exegetical method. In the twelfth century, Joachim distanced himself from a Christocentric view of history and claimed that history is the scenario of the Trinity 
working on it. He was not the first to divide history into three stages, according the Persons of the Trinity, but he had an innovative conception of it: the Age of the Father started from creation until the event of Incarnation, the Age of the Son covered history from His Incarnation to the time when Joachim was living, and the Age of the Spirit was about to be initiated (De Lubac 1979, I, 22). This understanding of history was also an exegetical claim, for if the Old Testament (Age of the Father) should be read along with the New Testament (Age of the Son), and every event in one of them had a correspondence with every event in the other (what Joachim called consonnantia or similitude aequae proportionis between both Testaments), then a New time of the Spirit would "open the seals" and reveal the real meaning of the Sacred Scriptures by the work of the Holy Spirit. The Age of the Spirit would unify the two Peoples of the Old and the New Testaments, both under two different rules or laws, and would bring them together under the one rule of freedom. Hence, Joachim characterises the Age of the Spirit as a time when the Earth would know "truth and peace", when freedom is finally achieved: whereas the Fist Age of the Father was but the emancipation from the natural elements of the world, and the Second Age of the Son was the emancipation from the Law, the Age of the Spirit would reveal the ultimate and true freedom (de Lubac 1979, I, 52).

The importance of Joachim for twentieth-century theology resides in his understanding of the deification that men go through by the indwelling of the Spirit. The movement in the history of Redemption from men as being the servants (Age of the Father), to their adoption as sons (Age of the Son), comes to an end in their becoming friends of God (Age of the Spirit). If deification has still a key role in the theology of the twentieth century (Olson 2007), it is in the work of Moltmann where this participation in the life of God is fully developed in a political perspective and under the influence of Joachim. The Trinitarian history of the three Ages is pointing towards the eschaton, i.e. to the Kingdom of Glory that would accomplish the destiny of the other Ages, a Kingdom "in which people will finally, wholly and completely gathered into the eternal life of the triune God and -as the early church put it- be deified ( $\theta \dot{\varepsilon} \omega \sigma \iota \varsigma) "(M o l t m a n n$ 1993, 213). If the trinitarian doctrine of the trinity is the theological doctrine of free- 
dom, this trinitarian history finds a kind of progression towards this ultimate freedom in the Kingdom of Glory. The kingdom of the Father pointed to the dependency of every creature to their Creator and preserver, and men were to be considered as the "servants" of God. The Kingdom of the Son changed this quality of being servants inwardly, for now men became the "children" of the Father, and this new relationship entailed that men were no longer God's servants or properties, but that they were the Father's heirs. In the Kingdom of the Spirit, there is a new inward change in the status of creatures, for now the servants and children of the Father become God's friends and, "by virtue of the indwelling of the Holy Spirit, people enter into this new 'direct' relationship with God" (Moltmann 1993, 220). The distance that both servant and children entailed between the ruler and the ruled ceases to exist in friendship: friends share power and rule. For Moltmann (quoting Hegel), "friendship is the concrete concept of freedom" (Moltmann 1993, 221). Still, even the freedom of God's friends is not yet complete freedom, and the perfect freedom is only to be found in the perfect bliss of the kingdom of glory, when we will know God "face to face", and the freedom of the servants, the children and the friends of God will find its fulfilment in God himself. Until we participate in God's eternal trinitarian life, "our hearts are restless"; or, paraphrasing Augustine in terms of freedom, "our hearts are captive until they become free in the glory of the triune God" (Moltmann 1993, 222).

We are invited to participate in this glorious Trinity, and we can participate by means of sanctification. From Early Christianity, the activity that defined the Spirit was sanctification, and the process by which human beings become god-like ( $\theta \varepsilon \dot{\varepsilon} \omega \sigma \iota)$ ) is but the performance of the Spirit (Lawreszuk 2006). Although the "exchange formula" of Irenaeus of Lyon (God became a man, so men can become like God) was the basic understanding of deification (Russell 2004, 106-110), it is paramount to stress that Jesus was considered to be God because He was full of the Spirit, that is, because He was absolutely obedient to His Father. In this way, again, we could understand that the idea of dispensatio is dependent on the idea of dispositio, and that if Jesus is the mediator between men and God, that is only possible because of the sanctifying action of the Holy 
Spirit that relates the Son to the Father, and that relates men to Jesus Christ by means of grace and the sacraments.

\section{Apokatástasis: the pneumatological reappropriation of history}

The dialectical tension between God's nature (immanent Trinity) and God's revelation (economic Trinity) in history that keeps deification far from being achieved, is only surpassed in the eschaton, when we become part of the inner life of God Himself, according to the Pauline verse, "God will be all in all" (1 Corinthians, 15:28). Hope aims, therefore, at this ultimate unity of everything, at the overcoming by God of every faction that makes His Sovereignty still not a perfect one. Whereas in history, unity is (already) performed, but not (yet) fulfilled, in the eschaton, everything will be at rest, in the peace of ultimate unity. God's essence - reflected in the Trinitarian doxology, celebrated in liturgy - is to be found in the Sabbath, the time after time, the eternal moment that knows no history.

In this hope for ultimate unity, the Holy Spirit is the key agent that performs unity. If oíкоvouí $\alpha$ is the activity of a God that turns plurality into unity, and if this unity is, in the ultimate sense, God's appropriation of everything in the world to perform a perfect and indivisible system, then it is not surprising that there is a semantic link between the Stoic idea of oikeiosis (the appropriation of the body proper, but also the building of a single cosmic and political Body) and the Christian idea of apokatástasis, which meant for Gregory of Nysa the re-appropriation of all things by the Godhead (Ramelli 2014). Within this task of God's reappropriation of His creatures, the political performance of the Spirit is especially highlighted within the frame of theodicy, for it brings forward the unity and peace of the Kingdom of God, albeit the negativity of historical events. The theological-political importance of the Spirit resides in this power to overcome the negative, even death and desolation. In the analogical meaning of the term 'spirit', that is applied both to the spiritual life of man and to the spirit of God (both kinds of lives that perfectly met in the person of Jesus Christ), Hegel claimed: 
The life of the spirit is not a life that is fearing death and austerely saving itself from ruin; rather, it bears death calmly, and in death, it sustains itself. Spirit only wins its truth by finding its feet in its absolute disruption. [...] Spirit is this power only by looking to the negative in the face and lingering with it. This lingering is what in the magical power that converts it into being (Hegel 2018, 21).

We could, then, ask if theodicy, even in the new eschatological understanding of theodicy, is not still too dependent on the ideal of unity and on the paradigmatic synthetic work of the Holy Spirit. It seems that the burning of the innocent children, although it is not happening under God's plan, is justified by God - in the end. A doxological kind of theology, such as Moltmann's, and this overcoming and arranging of the Spirit, is still too dependent on the idea of an "Almighty God" that will force everything towards its Kingdom. But it seems that the very idea of theodicy (in both meanings as an apology of God and as God's arranging performance of the world) cannot escape from the need to affirm this Omnipotence, for Omnipotence is the very ground for doxology (the act of giving Glory to God). I do wonder, in fact, if there is any Christian theology that is not theodicy, that is, I wonder whether there is a way to think about God's covenant with men beyond the categories of sovereignty and glory. Perhaps this negation to accept any theodicy whatsoever would entail to do justice to the negative, without subsuming it to God's plan (Zathureczky 2004). If one wishes to aim at a new Christian theology, where the political paradigm of sovereignty is surpassed - an attempt that is found, for instance, in the work of John Caputo (2006)-, a critical examination and a new understanding of the Holy Spirit seems necessary. I am certain that we are not going to be able to open new theological horizons until we face directly the Spirit that haunts us and that performs this all-embracing politics of God that seems to forget singularity and plurality in the name of the One, and that forgives and forgets everything in the name of the eschatological peace, in our wreck into the uninterrupted and undivided life of God. Perhaps only an alternative understanding of the Trinity that stresses plurality over unity, difference over homogeneity, could finally escape from the despotic and monarchical scheme of Christian 
theology; perhaps only a purely negative eschatology could avoid writing history from the end, as being the economic re-appropriation story of the One Sovereign and his many servants ${ }^{1}$.

\section{References}

Agamben, Giorgio. 2011. The Kingdom and the Glory: For a theological Genealogy of Economy and Government. Stanford: Standford University Press.

Althouse, Peter. 2006. "In appreciation of Jürgen Moltmann: A Discussion of His Transformational Eschatology." Pneuma: The Journal of the Society for Pentecostal Studies 28(1): 21-32.

Assmann, Jan. 2000. Herrschaft und Heil. Politische Theologie in Altägypten, Israel und Europa. Munich-Vienna.

Augustine of Hippo. 2003. The City of God. Translated by Henry Bettenson. London: Penguin Books.

Balan, Bernard. 1975. "Premières recherches sur l'origine et la formation du concept d'économie animale.” Revue d'Histoire des sciences 28/4: 289-326.

Basile de Césarée. 1968. Sur le Saint-Esprit. Paris: Les Éditions du Cerf.

Batut, Jean-Pierre. 2009. Pantocrator: "Dieu le Père tout-puissant" dans la théologie prénicéenne. Paris: Institut d'Études Augustiniennes.

Caputo, John. 2006. The Weakness of God. A Theology of the Event. Indiana University Press.

Congar, Yves. 1975. Un people messianique: L'Église, sacrament du salut; Salut et liberation. Paris: Cerf.

Cross, Richard. 2000. "Perichoresis, Deification, and Christological predication in John of Damascus." Mediaeval Studies 62: 69-124.

De Lubac, Henri. 1979. La postérité spirituelle de Joachim de Flore. Paris; Namur: Éditions Lethielleux; Culture et Vérité. 2 volumes.

Geddes, Jennifer. 2018. "Theodicy, Useless Suffering, and Compassionate Asymmetry: Primo Levi, Emmanuel Levinas and Anti-Theodicy.” Religions 9/114: $1-8$.

Grassi, Martín. 2019. “A Self-Moved Mover: The paradigm of autarchy in Jürgen Moltmann's theology.” International Journal for Philosophy and Theology 80/3: 197-214.

1 This paper is an outcome of my research as an Alexander von Humboldt Fellow at the Institüt für Hermeneutik, Faculty of Protestant Theology, University of Bonn, Germany. 
Grassi, Martín. 2020. "Self-organized bodies, between Politics and Biology. A political reading of Aristotle's concepts of Soul and Pneuma." Scientia et Fides 1: 123-139. DOI: http://dx.doi.org/10.12775/SetF.2020.005

Hegel, G. W. F. 2018. The Phenomenology of Spirit. Cambridge: Cambridge University Press.

Iiritano, Massimo. 2018. “The Reception of Joachim in Contemporary Theology and Postmodern Philosophy”, in: Riedl, Matthias. A Companion to Joachim of Fiore. Leiden-Boston: Brill, pp. 319-345.

Lawreszuk, Marek. 2016. "The Role of the Holy Spirit in Human Deification.” ELPIS 18: 21-26.

Leshem, Dotan. 2012. “The ancient art of economics.” European Journal of Economic Thought: 1-29.

Moltmann, Jürgen. 2002a The Theology of Hope. London: SCM Press.

Moltmann, Jürgen. 1968. “Hope and History.” Theology Today 25, n. 3 (October).

Moltmann, Jürgen. 1992. The Spirit of Life: A Universal Affirmation. Minneapolis: Fortress Press.

Moltmann, Jürgen. 1993. The Trinity and the Kingdom: The doctrine of God. Minneapolis: Fortress Press.

Moltmann, Jürgen. 2002b. „Kein Monotheismus gleicht dem anderen. Destruktion eines untauglichen. Begriffs.“ Evangelische Theologie 62/2: 112-122.

Olson, Roger. 2007. “Deification in Contemporary Theology.” Theology Today 64: 186-200.

Peterson, Erik [1935] „Der Monotheismus als politisches Problem“, in: Peterson, Erik (1950). Theologische Traktate. München: Im Kösel Verlag zu München: 45-148.

Ramelli, Ilaria. 2014. „The Stoic Doctrine of Oikeiosis and ist Transformation in Christian Platonism.“ Apeiron 47/1: 116-140.

Riedl, Matthias. 2018. “Longing for the Third Age: Revolutionary Joachism, Communism, and National Socialism”, in: A Companion to Joachim of Fiore. Leiden-Boston: Brill, 267-318.

Rikhof, Herwi. 2009. "The current Renaissance of the Theology of the Trinity : A reconstruction”, Bijdragen International Journal in Philosophy and Theology, 70/4: 423-457.

Russell, Norman. 2004. The doctrine of deification in the Greek Patristic tradition. New York: Oxford University Press.

Ruz, Matías Omar; Rosolino, Guillermo; Schickendantz, Carlos. 2008. "Razón anamnética, sufrimiento ajeno y teodicea. Claves de lectura, logros y límites de la obra de Johann Baptist Metz.” Teología y Vida XLIX: 575-603. 
Schmitt, Carl. 1970. Politische Theologie II: Die Legende von der Erledigung jeder Politischen Theologie. Berlin: Duncker \& Humblot.

Schmitt, Carl. 2009 [1922]. Politische Theologie: Vier Kapitel zur Lehre von der Souveränität. Berlin: Duncker \& Humblot. Neunte Auflage.

Taubes, Jacob. 2009. Occidental Eschatology. Stanford: Stanford University Press.

Tertullian. 1948. Tertulliani Adversus Praxean Liber. Translation: Evans, Ernest. Tertullian's Treatise against Praxeas. London: SPCK.

Uríbarri, Gabino. 1996. Monarquía y Trinidad. Madrid: Universidad Pontificia Comillas.

Uríbarri, Gabino. 2003. “La reserva escatológica: un concepto originario de Erik Peterson.”Estudios eclesiásticos 78: 29-105.

Verbeke, Gérard. 1945. L' évolution de la doctrine du pneuma du stoïcisme à S. Augustin: étude philosophique. Paris: Desclée de Brouwer.

Wartelle, André. 1968. “"Introduction» and «Notes complémentaires». Aristotle.” Économique. Paris: Les Belles Lettres.

Zathureczky, Kornel. 2004. A critique of the messianic theology of J Moltmann through the messianic philosophy of W Benjamin: Staying with the negative. $\mathrm{PhD}$ Dissertation. 